\title{
Populist Rhetorical Strategies in the Courts of Classical Athens
}

\author{
By Vasileios Adamidis*
}

\begin{abstract}
The elusive populist phenomenon has been the focus of numerous studies in recent years, with the reliance of populism on divisive and aggressive rhetoric being acknowledged. The paper aims to apply these findings to the Athenian forensic rhetoric and identify manifestations of populist rhetoric in the antagonistic arena of Athenian courts. By reference to the most 'political' of public trials, namely the indictments against inexpedient laws and illegal decrees, it is argued that the rhetorical strategies employed by the Athenian litigants who sought to persuade mass audiences in a zero-sum process, have much in common with modern populist discourse. Aiming to secure the good will of the dicasts, speakers competed over their level of adherence to the shared traditional values and norms of Athenian society, making the audience the nodal point of their rhetoric. Artfully interpellating the audience into a fictitiously pure and homogeneous group, litigants sought to establish concord with the dicasts while alienating the opponent. The division between the pure demos and the corrupt establishment, allowed the speakers to use a divisive and aggressive rhetoric, through which the adversary was presented as an outsider, representative of the out-group of corrupt political elite who undermined the political and moral principles upon which the Athenian identity was based.
\end{abstract}

Populism is an essentially contested concept that is hard to define ${ }^{1}$. It has been classified, inter alia, as ideology ${ }^{2}$, strategy ${ }^{3}$, political $\operatorname{logic}^{4}$, rhetoric ${ }^{5}$, and

"Principal Lecturer, Nottingham Trent University, UK.

1. For the definition of 'essentially contested concepts' see W.B. Gallie, "Essentially Contested Concepts," Proceedings of the Aristotelian Society 56, no. 1 (1956): 169. For populism as an 'essentially contested concept' see Cas Mudde, "Populism: An Ideational Approach," in The Oxford Handbook of Populism, edited by C. Rovira Kaltwasser, P. Taggart, P. Ochoa Espejo, P. Ostiguy (Oxford: Oxford University Press), 27-47.

2. For populism as an ideology, see Cas Mudde, "The Populist Zeitgeist," Government and Opposition 39, no. 4 (2004): 543; Koen Abts and Stefan Rummens, "Populism versus Democracy," Political Studies 55, no. 2 (2007): 405-424; Ben Stanley, "The Thin Ideology of Populism," Journal of Political Ideologies 13, no. 1 (2008): 95-110; Cas Mudde and Cristobal Rovira Kaltwasser "Populism and (Liberal) Democracy: A Framework for Analysis," in Populism in Europe and the Americas: Threat or Corrective for Democracy?, edited by Cas Mudde and Cristobal Rovira Kaltwasser, (Cambridge: Cambridge University Press, 2012), $1-26$.

3. Kurt Weyland, "Clarifying a Contested Concept: Populism in the Study of Latin American Politics," Comparative Politics 34, no. 1 (2001): 14. For populism as a strategy, see Robert R. Barr, "Populists, Outsiders and Anti-Establishment Politics," Party Politics 15, no. 1 (2009): 29-48.

4. Ernesto Laclau, The Populist Reason, (London: Verso, 2005).

5. Martin Reisigl, "Analyzing Political Rhetoric," in Qualitative Discourse Analysis in the Social Sciences, edited by Ruth Wodak and Michał Krzyżanowski, (New York: Palgrave Macmillan, 2008). 
discourse ${ }^{6}$. Promises of power for the many, not for the few (members of the elite), are increasingly present in modern political discourse and shape the ideological framework, especially, of liberal democracies. Despite the true beliefs and objectives of populist leaders, rhetoric is their main vehicle for mobilizing the masses and persuading large audiences about the sincerity of their intentions. Populist rhetoric is predominantly an appeal that pits the (often marginalized and discontented) pure 'People', the common citizens, against an out-group, often loosely defined 'establishment', 'elite' or oligarchy'7. The focus of this type of rhetoric lies on the mode of political expression evident in text, speech, and performance, which might eventually, allow populists to dominate the political field and monopolize the political discourse.

Populist rhetoric is divisive, antagonistic, anti-pluralist, and often aggressive ${ }^{8}$. Its strategic objective is the effective manipulation of the People's thoughts and emotions, by artfully interpellating them as a homogeneous group with putatively common identity and interests, whose just demands and rights are denied by the establishment and the ruling elite. This is an artificial construction, at best referring to a specific interpretation (and simplification) of reality. ${ }^{9}$ The tactics used to implement this strategy are, initially, to interpellate the fictional group of 'pure' People, who are often described as (or feeling) vulnerable, by creating bonds between them through the cultivation of a shared identity by reference to common values ${ }^{10}$. The People are, subsequently, pitted against an equally fictional and oversimplified Corrupt and Voracious Elite, separating the two groups by creating clear boundaries, binaries, and dichotomies.

The aim of this paper is to trace manifestations of populist rhetorical strategies in the classical Athenian forensic speeches. The antagonistic nature of the Athenian administration of justice and the need to persuade large audiences

6. Kirk A. Hawkins, "Is Chavez Populist? Measuring Populist Discourse in Comparative Perspective," Comparative Political Studies 42, no. 8 (2009): 1040-1067; Carlos De La Torre, Populist Seduction in Latin America, (Ohio: Ohio University Press, 2010); Michael Kazin, The Populist Persuasion, (Ithaca, NY: Cornell University Press, 1995). For populism as style, which takes in both the rhetorical and the aesthetic aspects of populist communication, rather than merely discourse, see Benjamin Moffitt, The Global Rise of Populism: Performance, Political Style and Representation, (Stanford, California: Stanford University Press: 2016).

7 See, for example, Cas Mudde and Cristobal Rovira Kaltwasser, "Studying Populism in Comparative Perspective: Reflections on the Contemporary and Future Research Agenda," Comparative Political Studies 51, no. 2 (2018): 1669.

8 Populism is anti-pluralistic as illustrated by Jan-Werner Müller, What Is Populism? (University of Pennsylvania Press 2016).

9 Cas Mudde and Cristobal Rovira Kaltwasser, Populism. A Very Short Introduction, (Oxford: Oxford University Press 2017): 9.

10 See Margaret Canovan, "Taking Politics to the People: Populism as the Ideology of Democracy," in Democracies and the Populist Challenge, edited by Yves Mény and Yves Surel (New York: Palgrave, 2002): 26. 
of Athenian citizens sitting and judging in the courts, created the ideal forum for the implementation of populist strategies. In particular, the main focus will be on the most 'political' of legal actions, namely the actions against inexpedient laws and illegal proposals. It will be shown that litigants consciously aim to establish concord with the homogeneous group of judges-People, which is the nodal point of their rhetoric, by demonstrating their adherence to common values and shared norms. Judges are presented as the embodiment of the eternal, transcendent Athenian demos. Subsequently, this interpellation of the Athenian judges-People and the identification of the speaker with them ${ }^{11}$, forms the basis for the alienation of the opponent, who is presented as an outsider, disrespectful of Athenian values, enemy of the People, the laws, and the democracy ${ }^{12}$.

\section{Securing the Good Will of the Audience}

In the antagonistic setting of Athenian courtrooms, litigants strove to win at all costs. Despite the (sometimes, unclear and flexible) rules and procedures of Athenian law promoting a more objective administration of justice ${ }^{13}$, securing the good will of the audience was crucial ${ }^{14}$. From the prooemium to the epilogue, speakers aimed at establishing concord with their hearers ${ }^{15}$, simultaneously undermining their opponent's credibility. According to Aristotle, this good will may reach its climax and imitate 'friendship' and, with the speaker's aggressive and antipluralist prompting, the audience is induced to more passionate and partial responses. ${ }^{16}$ Although this was prohibited by the Heliastic oath taken by all Athenian judges (Dem. 24.151), the mere presence of such a clause reveals the existence of the problem. The most characteristic example comes from a speech

11. For examples of such identification of the speaker with the audience, see Dem. 18.281, 287, 292-3; 20.4, 14; 23.6, 163-6, 173-4, 184, 194; 24.24, 38.

12. Vasileios Adamidis, Character Evidence in the Courts of Classical Athens: Rhetoric, Relevance and the Rule of Law, (London and New York: Routledge, 2016), chapter 5.

13. Edward M. Harris, The Rule of Law in Action in Democratic Athens, (New York: Oxford University Press, 2013).

14. On securing the good will (eunoia) of the audience, see Adamidis, Character Evidence, 209. Reference to public services (liturgies) was also an evidently effective tactic to ask for the gratitude (charis) or for the good will of the people, see Vasileios Adamidis, "The Relevance of Liturgies in the Courts of Classical Athens," Athens Journal of History 3, no. 2 (2017): 85-96.

15. Aristotle, Nicomachean Ethics 1167a-b; Aristotle Rhetoric 1378a19; cf. Arist. Nic. Eth. 1166b33 where good will is described as 'less intense philia'; William Fortenbaugh, "Aristotle on Persuasion through Character", Rhetorica, 10, no. 3 (1992): 219-220.

16. For a study of such responses in the courts, see Victor Bers, "Dikastic Thorubos", History of Political Thought 6, no. 1/2 (Summer 1985): 1-15. 
delivered by Apollodorus (Dem. 45) against Stephanus for false testimony. Apollodorus says that his opponent

"made such an impression on the jury that they refused to hear a single word from me: I was fined one sixth of the amount claimed, was denied the right of a hearing, and was treated with such contumely as I doubt if any other man ever was, and I went from the court, men of Athens, taking the matter bitterly and grievously to heart."17

Although such episodes may be described as "aberrations from the norm" where the court "have yielded to emotional appeals and failed to perform their duty of upholding the law"18, they nonetheless highlight the untypical emergence of passionate good will towards one of the parties, leading to antipluralism and reaching the extent of prejudice. In order to achieve this end, litigants resorted to strategies which, in modern discourse, could be described as 'populist'. These include the interpellation of the audience (the People) in a single, homogeneous, group by reference to common shared values, flattering them as pure, misled, and unaccountable ${ }^{19}$ and, then, pitting them against the marginalized opponent. For example, Hyperides, in Against Demosthenes, says that:

“The People have always treated <us politicians in this way>: although stripped of their own crown by fortune, they have not stripped us of the one they awarded. When the people have behaved towards us in this way, shouldn't we render all the service that is rightfully due them and, if need be, die for them? But you <acted> against the interests of the people."20

Treating the people as the nodal point and flattering them ${ }^{21}$ was a safe way to ask for their good will. For this tactic to be effective, the interpellation of this group as homogeneous and pure was a prerequisite.

\section{Interpellation of the 'People'}

In Athenian forensic speeches, it is not uncommon for litigants to refer to the judges as to one single unit, all belonging in the same group; as if the same people who sit in the court judging the particular case, also sit in the Assembly during

17. Demosthenes (speech) 45 (section) 6, to be cited as Dem. 45.6.

18. Edward M. Harris, "Law and Oratory," in Persuasion: Greek Rhetoric in Action, ed. Ian Worthington, (London: Routledge, 1994), 137.

19. Dem. 18.208, 18.277; Dem. 22.11; 23.97; Aeschines (to be cited as Aes.) 3.142, 3.231.

20. Hyperides (to be cited as Hyp.) 5.30 .

21. E.g. Hyp. 4.33. 
any (past or future) debate, exhibiting the same behavioral traits and characteristics $^{22}$. Judges are addressed in the second person plural, being distinguished from other groups such as the generals and politicians. For example, in Hyperides 5, fr. 6 it is said: "Gentlemen of the jury, you readily allow the generals and politicians to make large profits, not because the laws grant them this right but because of your indulgence and generosity." Demosthenes uses similar arguments referring to a homogeneous group mentality ${ }^{23}$ and suggests that his opponents have gotten "you [Athenian people] into the habit of losing confidence in yourselves and admiring one or two men." 24

The People sitting in court are presented as the nodal point of Athenian politics. This is characteristic of modern populist rhetoric ${ }^{25}$, yet in the direct democracy of Athens it was certainly true in its most literal sense. There, every proposal, by law, had to promote the best interests of the people. Legal actions could be brought for misleading the Athenian $\operatorname{demos}^{26}$ which had the ultimate decision-making power in the Assembly. Also, the segment of the demos sitting in court had the power of a final, unappealable, verdict. Hyperides, acknowledging this fact, criticizes his opponent Philippides for not treating the

22. The extent to which the judges sitting in courts represented the demos of the Athenians has caused some controversy, though it is likely that judges were mainly taken as representing the demos; on the relevance of synecdoche for relations between the demos and smaller groups representing it, see Josiah Ober, The Athenian Revolution: Essays on Ancient Greek Democracy and Political Theory, (Princeton: Princeton University Press, 1996): 118-9; cf. Paul Cartledge, Democracy: A Life, (Oxford: Oxford University Press, 2016): 17. However, judges swore an oath individually (the Heliastic oath) and voted individually. See A.J.L. Blanshard, "What Counts as the demos? Some Notes on the Relationship between the Jury and "The People" in Classical Athens," Phoenix 58 (2004): 32.

23. Dem. 23.206.

24. Dem. 23.210; cf. Aes. 3.178.

25. Yiannis Stavrakakis \& Georgios Katsambekis, 'Left-wing populism in the European periphery: the case of SYRIZA' in Journal of Political Ideologies, 19.2 (2014), 119-142.

26. I use the 'People' and the 'Demos' interchangeably, although the latter might be seen as a more clearly and restrictively delineated group. In modern discourse, the 'People' refers to a homogeneous, almost transcendent, group which might include people with no right to vote, such as minors and immigrants (although the latter are usually - in Right wing populist rhetoric - presented as outsiders who assist in the binary definition of the 'People'). The 'Demos' on the other hand was a group clearly defined by law and, thus, its interpellation was easier. Yet, appeals to the 'Demos' in Athens shared many common features with appeals to the 'People' in modern populist discourse. Cf. references to the demos in the Athenaion Politeia, in the Old Oligarch ([Pseudo-Xenophon], Constitution of the Athenians) and in Thucydides, History of the Peloponnesian War, usually describe a rigid polarization between the nobles and the mass of the people, the latter term referring to the unprivileged (Peter J. Rhodes, A Commentary on the Aristotelian Athenaion Politeia, (Oxford: Clarendon Press, 1981), 88, 97. 
People as the nodal and powerful point of Athenian politics; instead, he says, Philippides chose to affiliate himself with their enemies:

"For you have not laid up for yourself any good will with the people of Athens but have invested elsewhere, and you thought of flattering only those who strike fear in the people, not those who now have the power to save you." 27

The people, frequently referred to as the 'Many' (bringing in mind the modern populist discourse), have emerged since the fifth century as the dominant unit of Athenian politics ${ }^{28}$. The democracy could be defined, in Aristotle's words, as the rule of the 'Many', predominantly poor, now interpellated in one single unit $^{29}$. This was reflected in the forensic rhetoric too. Demosthenes, in order both to create a sense of group identity among the judges and to convince them to decide against the honors proposed for the general Charidemus by his opponent, has the speaker saying that "in the past the city was wealthy and famous in public, but no one in private rose above the Many" 30 before criticizing the current state of affairs whereby the few enrich themselves at the expense of the people. The 'Many' are pure and unaccountable; they are deceived by the shrewd politicians ${ }^{31}$.

A further method that speakers implemented for interpellating the People was to create the fiction that the segment of the demos before them was part of an abstract, timeless, and transcendent Athenian demos. Aeschines, says to the judges: "I shall provide your law, which you passed with the intention...", 32 as if it

27. Hyp. 2.7; cf. Hyp. 4.29-30.

28. Thucydides (2.37), in the Funeral Oration delivered in honor of the Athenian war dead, has Pericles saying that the 'constitution is called a democracy because we govern in the interests of the majority, not just the few'. Cf. references to the demos as the Many in pseudo-Xenophon's [Ath. Pol.]. Despite their regular bias, ancient sources usually describe a rigid polarisation between the nobles and the mass of the people with the term demos referring, as a norm, to the unprivileged; see Peter J. Rhodes, A Commentary on the Aristotelian Atlenaion Politeia, (Oxford: Oxford University Press, 1981): 88, 97; cf. Martin Ostwald, From Popular Sovereignty to the Sovereignty of the Law: Law, Society, and Politics in Fifth-Century Athens, (Berkeley, Los Angeles, London: University of California Press, 1986); W.R. Connor, The New Politicians of Fifth-Century Athens, (Princeton, N.J.: Princeton University Press, 1971).

29. Aristotle Politics 1292a11. For manifestations of populism in late fifth century Athens, see Vasileios Adamidis, 'Manifestations of populism in late 5th century Athens', in New studies in law and history, eds. David. A. Frenkel \& Norbert Varga, (Athens: Athens Institute for Education and Research, 2019), 11-28.

30. Dem. 23.206.

31. Dem. 23.97.

32. Aes. 3.14. 
was the same people who voted for this law in the Assembly ${ }^{33}$. Similarly, Demosthenes addresses the judges before him as if they were the ones who took certain decisions in the Assembly in the past ${ }^{34}$. In another case, Demosthenes, compares the heroic achievements of previous generations with those of the current one, referring to the latter as being accomplished by the people before him in the court:

"That is how your ancestors acted, and that is how you older men acted when the Thebans defeated the Spartans at Leuctra and tried to destroy them. You prevented it...You did not fear the power and reputation of Thebans...you showed all Greeks that when someone wrongs you in public policy you should look to the standards of your forebears" 35 .

Such references were not always the case as, at times, speakers distinguish between the different sets of men taking the decisions. Yet, they still refer to them as a homogeneous group that should behave as belonging to the timeless group of Athenian citizens:

"Even if it was one set of men who were saved and granted the exemption, but you, who are the ones now taking it away, constitute a different group, that does not remove the stain on your reputation" ${ }^{\prime \prime 6}$.

This brings us to the next point which is the putative ethical homogeneity among the generations of the timeless Athenian demos. References to the Athenian ancestors were frequent and, inter alia, served the objective of the further interpellation of the group. Speakers present themselves as adhering to these values, which the opponent subverts, urging the judges to demonstrate their loyalty to their ancestors and the Athenian tradition by punishing the dissenter ${ }^{37}$. Demosthenes, defending his record of policy proposals, argues that these aligned with the practices of the ancestors that shaped the Athenian character. Referring to various incidents of the distant and recent past ${ }^{38}$ that reveal the disposition of the Athenians ${ }^{39}$, justifies his policies by arguing that: "Since I had seen so many instances of this kind where the city was ready to fight

33. Cf. Aes. 3.37, 3.232.

34. Dem. 20.12.

35. Dem. 18.98-99; cf. 18.96; Dem. 20.60, 20.68, 20.72, 20.86, 20.109; 22.6, 22.10. For the rhetorical techniques followed by the Attic orators when using examples from the past, see Giulia Maltagliati, "Persuasion through proximity (and distance) in the Attic orators' Historical Examples," Greek, Roman, and Byzantine Studies 60, No. 1 (2020): 68-97.

36. Dem. 20.47.

37. Aes. 3.112, 3.231.

38. Dem. 18.96-101.

39. Dem. 18.100. 
for the interests of others, what was I to urge the city to do, what was I to advise?" 40 Ancestors, judges and Demosthenes adhere to common values, while Aeschines, who criticized Demosthenes for these policies, stands on the opposite side.

Speakers, appealing for conformity with the practices of the past that made Athens great, invite the audience not to deviate from their ancestors' tradition ${ }^{41}$. Aeschines, advising the audience not to honor Demosthenes by awarding him a crown for exceptional services to the city, contrasts the ancestral practices to the current situation:

"If anyone were to ask you whether in your opinion the city is more renowned at the present time or in our ancestors' time, you would all agree that it was in our ancestors' time. And were men better then or now? Then they were outstanding, now they are far inferior. And were the awards and crowns and proclamations and free meals in the Prytaneum more plentiful then than now? In those days distinctions were scarce in our city, and the name of virtue was an honor. Now the whole practice has been completely discredited, and you give crowns out of habit, not on purpose" 42 .

The invocation of political ideals could further assist in the interpellation. Adherence to the rule of law was a widely acknowledged Athenian value stemming from the Athenian tradition. Demosthenes says that

"our ancestors founded this court of law not so that we litigants could gather you together and then hurl the proscribed slurs at each other for personal reasons but to convict someone who may have committed a crime against the city. Aeschines knows this as well as I, yet rather than accuse, he has chosen to abuse" ${ }^{\prime 3}$.

Once again, the values and norms of the homogeneous Athenian demos are respected by the speaker, thus establishing concord ${ }^{44}$ and demonstrating loyalty to the ancestral institutions, while alienating the opponent who abuses and subverts Athenian tradition ${ }^{45}$.

40. Dem. 18.101.

41 Tradition as a type of legal argument is discussed in Wilson Huhn, The Five Types of Legal Argument, (Durham, NC: Carolina Academic Press, 2014): 45-50.

42. Aes. 3.178; for a very similar argument, cf. Dem. 23.196, 23.204, 23.211.

43. Dem. 18.123-4.

44. Dem 18.280.

45. This establishment of concord in order to provoke the friendly disposition of the audience is also suggested by Aristotle (e.g. Rhetoric 1381a, Nic. Eth. 1167a-b). This technique, aiming at the establishment of a special relationship of concord and unanimity between the speaker and the audience, is evident from Homer onwards. Although it is not 
Another frequently invoked part of the Athenian legal tradition was the persona of the 'lawgiver' ${ }^{\prime 6}$. Orators often resort to the authority of the lawgivers of the past, a topos of Athenian oratory, in order to support their case ${ }^{47}$. References to Solon and Draco reveal the timelessness and merit of Athenian laws, making each verdict of historical importance ${ }^{48}$. Judges, envisaged as representatives of the timeless and transcendent demos, stand in the court of history before the persona of the glorified lawgivers. Being the expressers and interpreters of the lawgivers' intent, judges belong to a venerated group with shared identity and values. Credit is reserved for the lawgivers, not for any public service except that they enacted beneficial and well-conceived statutes ${ }^{4}$, these being the 'currency of the state' and, therefore, if anyone debased that currency and introduced counterfeit, the court had graver reason to abhor and punish that man ${ }^{50}$. With a single argument, the group of Athenian judges is interpellated, the opponent is alienated and the speaker is presented as the defender of the Athenian values ${ }^{51}$. The authority-figure of the 'ideal lawgiver' demonstrated the ethical coherence of Athenian laws and the legal system's almost mystical continuity through time. This imagined figure impersonated the ethical prototype of the Athenian legal system, persuading the judges to interpret the Athenian laws, as far as possible uniformly, by reference to his demands ${ }^{52}$. As Aeschines urges them to do, combining the authority of the lawgivers with that of the ancestors:

evident solely in forensic settings (cf. Aristophanes Wasps; James F. McGlew, "Speak on my Behalf": Persuasion and Purification in Aristophanes' Wasps", Arethusa 37 (2004): 11-36.), it is in the Attic orators that it achieved its perfection (e.g. Antiphon 1.4; Dem. 18.280-1, 18.287,18. 292-3; 20.4, 20.14; 23.6, 23.163-6, 23.173-4, 23.184, 23.194; 24.24, 24.38; cf. Adamidis, Character Evidence, chapter 1.

46. Michael Gagarin, "Storytelling about the Lawgiver in the Athenian Orators," CEA (2020): 33. On Greek lawgivers, see Szegedy-Maszak, A., "Legends of the Greek Lawgivers," GRBS 19 (1978): 199-209; on Solon, see Edward M. Harris, "Solon and the Spirit of the Law in Archaic and Classical Greece," in Democracy and the Rule of Law in Classical Athens, edited by E. M. Harris (New York: Cambridge University Press, 2013): 329 and Vasileios Adamidis, "Solon the Lawgiver: Inequality of Resources and Equality before the Law," in the Role of law, human rights and social justice, justice systems, commerce, and law curriculum: selected issues, edited by David A. Frenkel (Athens: ATINER, 2017): 121138.

47. E.g. Aes. 3.2, 3.6, 3.22, 3.26, 3.31, 3.33, 3.38; Dem. 20.89-93; 23.27; 24.38 .

48. On the historical importance of decisions, see: Aes. 3.6-7, 3.14, 3.108, 3.112, 3.175, 3.178; Dem. 20.12,20. 89-93, 20.135, 20.142, 20.154; 22.35,22. 94-99; 24.38.

49. Dem. 24.211.

50. Dem. 24.213.

51. Cf. Aes. 3.175, Dem. 20.94; 24.38.

52. On the figure of the 'ideal lawgiver' and its implications see Stephen Johnstone, Disputes and Democracy: the Consequences of Litigation in Ancient Athens (Austin: University of Texas Press, 1999), 25-33; cf. Edward M. Harris, "Solon and the Spirit of the Law in Archaic Athens," in Democracy and the Rule of Law in Classical Athens: Essays on Law, Society, 
"[i]magine that you [judges] see on the platform where I now stand as I speak the city's benefactors ranged against their [Demosthenes and his supporting speakers] impudence. See Solon, who equipped the democracy with the noblest laws, a philosopher and a worthy legislator, urging you in the restrained manner that befits him under no circumstances to set more value on Demosthenes's arguments than on your oaths and the laws. See Aristides...expressing his anger at the insult to justice..." 53 .

Judges, as a group, ought to protect Athenian legal tradition. Demosthenes claims that Timocrates's law "robs the Courts of Justice, which are the pillars of the constitution, of all power to impose the additional penalties attached by the laws to transgressions" all the laws you have enacted for the restraint of the wrongdoers be invalidated and this law alone be valid?" 55 In support of his argument, Demosthenes highlights the antiquity of these "old-established" and "well-tried" laws ${ }^{56}$ which have been repeatedly tested and found advantageous, against the brand new law of Timocrates which threatens to destroy them ${ }^{57}$. According to him, "such a lawgiver merits the severest punishment...to prevent another man from coming forward to overthrow the most powerful institutions with a fresh statute"

The orators attribute the prosperity of Athens, her liberty, and her democracy to her laws that the judges are asked, as a group, to defend ${ }^{59}$. To the question "what is then the only honest and trustworthy safeguard of the law", Demosthenes replies: "you, the common people"60. Judges are frequently reminded to vote in accordance with the law, especially by reference to the Heliastic oath, another institution enforcing the common bonds and shared identity of Athenians ${ }^{61}$. Demosthenes warns the judges that:

and Politics, ed. Edward M. Harris, (New York: Cambridge University Press, 2006) 3-28. I borrowed the notion of the 'authority-figure' from Douglas L. Cairns, Aidoss: the psychology and ethics of honor and shame in ancient Greek literature (Oxford: Clarendon, 1993), 39, since I find its application to the Athenian legal system's context with its frequent invocation of the 'ideal lawgiver' suitable.

53. Aes. 3.257-8.

54. Dem. 24.2.

55. Dem. 24.5.

56. Dem. 24.24.

57. Dem. 24.137, 24.142.

58. Dem. 24.153.

59. Dem. 24.5.

60. Dem. 24.37.

61. Careful analysis of the court speeches reveals that references to the Heliastic oath weighed significantly to the minds of the jurors. On the statistics of the Heliastic oath in forensic speeches, see Johnstone, Disputes and Democracy, 33-45; Regarding the role and effect of the dikastic oath in Athenian courts, see Edward M. Harris, 'The rule of law in Athenian democracy. Reflections on the judicial oath', Dike 8 (2008): 157-81, contra 
"Now, you need to consider whether you value the constitution and the established laws and obedience to your oath as highly as this sum of money. If you are going to acquit a man who has obviously made an illegal proposal in this way, everyone will think you have chosen the sum of money over your laws and obedience to your oath...remember your oath and keep in mind the indictment: the issue now is not about collecting taxes but whether the laws should have authority" 62 .

Counter-interpellation, namely uniting the group by denouncing a common enemy, is also evident in the speeches. This common enemy is, naturally, the opponent, who poses a threat to the people and the democracy. Aeschines urges the judges to:

"[h]ate people who draft illegal decrees and regard no offence of this sort as insignificant but attach great importance to every one of them. And you should not allow any man to deprive you of this right, neither the supporting speeches from generals who have been colluding with certain public speakers to harm the constitution, nor the entreaties of foreigners, whom some people bring to stand and so get off free from the courts, even though their political conduct contravenes the laws. No, just as each of you would be ashamed to desert the post assigned to him in war, so now you should feel ashamed to desert the post of guardians of the democracy that the laws have assigned to you today... the whole citizen body has placed the city in your care and entrusted the constitution to you"63.

Demosthenes, setting boundaries between the citizens and the politicians and clearly designating the two distinct, opposing groups, says that:

"in private life there is such an excessive amount of private wealth belonging to men who conduct public business that they have constructed private houses more impressive than many public buildings, and some have bought up more land than all of you in the court possess...the men who manage our public affairs go from poverty to riches and supply themselves with plentiful livelihood for a long time. But you do not have enough money in the public treasury to supply even a day's travel expenses. In the past, the people were the master of the politicians but now they are their servants. The people who propose decrees like this one are responsible..."64.

Matthew R. Christ, The Litigious Athenian (Baltimore: Johns Hopkins University Press, 1998), 194-6.

62. Dem. 20.45-46.

63. Aes. 3.6-7.

64. Dem. 23.208-9; cf. Hyp. 4.36-8. 
The two groups were clearly distinguished: on the one hand, the pure People, interpellated by reference to noble objectives and shared values; on the other, the opponent, quite often presented as a member of the political or economic establishment ${ }^{65}$. The ground was paved for the second part of the populist rhetorical strategy.

\section{Divisive/Antagonistic Rhetoric}

The interpellation of the 'pure' People was the first step for the implementation of the populist rhetorical strategy of litigants. Defining and setting the criteria for the membership of this group, allowed the speaker to indicate adherents and outsiders $^{66}$. The relationship between them represents an antagonistic struggle on a 'friends and enemies' basis (the populist cosmology), in accordance with Carl Schmitt's influential distinction. ${ }^{67}$ The ultimate objective was, following a binary and Manichaeistic tactic, the exclusion of the opponent from the interpellated group. Following the interpellation which was given effect by reference to the shared, traditional values and norms, the opponent is accused of disrespecting and subverting them.

The most characteristic type of populist division is setting the common people against the political elite. Although the term rhetor (usually translated as 'public speaker' or 'politician' to conform to modern politics) could be used either in a neutral or in a negative way depending on the speaker's viewpoint ${ }^{68}$, the division between People and politicians is particularly evident in actions against illegal proposals where the accuser points to this capacity of the proposer. Hyperides suggests that such a division is envisaged by the law itself ${ }^{69}$ and argues for its validity throughout the speech ${ }^{70}$. Euxenippus, on whose behalf Hyperides speaks, is presented as a common citizen in order to be distinguished

65. Hyp. 4.32; Dem. 18.109; 20.1, 20.157; 22.42, 22.59.

66. The essential features of the populist ontology involve 'the people' and 'the outgroup(s)'. See Paul Taggart, "Populism and 'Unpolitics'," in Populism and the Crisis of Democracy, Vol. 1: Concepts and Theory, edited by G. Fitzi, J. Mackert, and B.S. Turner, (Lonsycopdon: Routledge, 2018): 79-80.

67. Carlos De La Torre and O. Mazzoleni, "Do We Need a Minimum Definition of Populism? An Appraisal of Mudde's Conceptualization," Populism 2, no. 1 (2020): 81-82.

68. Compare Dem. 24, written in 353 B.C.E. when Demosthenes was still at a young age, with Dem. 18 where Demosthenes defends his lifetime's career as a statesman. Cf. Mogens H. Hansen, "The Athenian 'Politicians', 403-322 B.C.," Greek, Roman and Byzantine Studies 24 (1983): 33-55; Dinarchus, Hyperides, and Lycurgus, Translated by Ian Worthington, Craig Cooper and Edward M. Harris, (Austin: University of Texas Press, 2001), 104, n.4.

69. Hyp. 4.4, 4.8.

70. Hyp. 4.36-8; cf. 5.12; cf. Hyp. fr. 80. 
from the rhetores ${ }^{71}$. It was certainly immoral for the prosecutor, Polyeuctus, to "prosecute private citizens...but [he] should prosecute a politician...or impeach a general"72.

Aeschines, refers to a "group that views politics as no longer a public activity but their own private preserve", scheming "to enslave ordinary men and maintain their own despotic power"73. In order to create a rift on the opponents' rhetorical strategy, still playing on this - evidently - popular theme, he says that Ctesiphon, the accused, "says that he is not afraid on his own account (he says he expects to be seen as an ordinary man $\left(i \delta \omega^{\prime} \tau \eta \zeta\right)$, but that what makes him afraid is Demosthenes's venality in political life" ${ }^{\prime 74}$ who, not missing a single day to engage in politics has marked himself as a "professional and a hireling"75. Judges should follow their ancestors' practice who "gave the credit for the glorious and brilliant achievements to the people but blamed humiliations and failures on shabby politicians" 76 . Otherwise, the judge, when he leaves the court, will realize that he:

"[w]ill have weakened himself and strengthened the politician. In a democratic city, the ordinary man has a king's power through the law and his vote... The fact that in the present circumstances, you the Many are abandoning the bastions of democracy to the Few, I cannot approve...Won't you keep the politicians under your control?"77

Unsurprisingly, given the popularity of this rhetoric, Demosthenes resorts to similar argumentation when it suits his aims. Replying to Aeschines, conforming to the populist 'anti-politicians' rhetoric, he says that:

"[h]e calls me a skillful speaker, a sorcerer, a sophist, and other such names. He hopes that by preemptively ascribing his own attributes to another, this description will be accepted, and the audience will not consider any further what kind of person is saying these things" ${ }^{\prime \prime 8}$.

In Against Androtion Demosthenes argues against the group of men who are eloquent and bold, mislead the people and might try to overthrow the democracy ${ }^{79}$. He advises the judges:

71. Hyp. 4.13.

72. Hyp. 4.27 .

73. Aes. 3.3, 3.20

74. Aes. 3.214 .

75. Aes. 3.220; cf. Dem. 22.4, 22.25, 22.32; 23.5.

76. Aes. 3.231; cf. Dem. 23.199.

77. Aes. 3.231-5.

78. Dem. 18.276.

79. Dem. 22.31-2. 
"[i]f you acquit, the Council house will fall into the hands of those who make speeches, but if you convict, into the hands of ordinary citizens...If this will happen and you get rid of the usual gang of orators, you will see everything works as it should, men of Athens" 80 .

In Against Aristocrates, Demosthenes has Euthycles saying that "you would be justified, men of Athens, in paying attention to me and to listening favorably to what I say. I am not one of those people who pester you, nor am I one of those politicians who enjoy your confidence" 81 . It is the politicians who have misled the people, so Euthycles hesitated to bring an action as "even though speaking the truth, I [he] would have less influence than many people telling you lies" ${ }^{\prime \prime}$. The city has been damaged "because of the depravity of the cursed and god-forsaken politicians ready to propose decrees like this"83. In Against Timocrates, Demosthenes argues that the people are "far more magnanimous than the politicians" ${ }^{\prime \prime 4}$ as:

"[p]oliticians rarely let a month go by without legislating to suit their private ends. When in office they are always haling private citizens to jail; but they disapprove of the application of the same measure of justice to themselves...if you [judges] decline to punish the men before you, in a very little time the People will be in slavery to those beasts of prey" ${ }^{\prime \prime 5}$.

As in modern discourse, politicians (and, naturally, the opponent is presented as such) are presented as corrupt. Inexpedient advice, changes in the attitude, and putatively inconsistent behavior, were all attributed to corruption rather than to a change of mind or circumstances ${ }^{86}$. Referring to the Harpalus affair, Hyperides scolds the Athenian people for allowing "generals and politicians to make large profits" 87 whom Harpalus bribed for political reasons ${ }^{88}$. This was not the first time that Demosthenes was accused of being bribed ${ }^{89}$ nor was it surprising that Demosthenes retaliated in the same way ${ }^{90}$. Yet, the centrality of such allegations in the litigants' discourse proves the credibility of such allegations for the Athenian judges. Therefore, having interpellated the

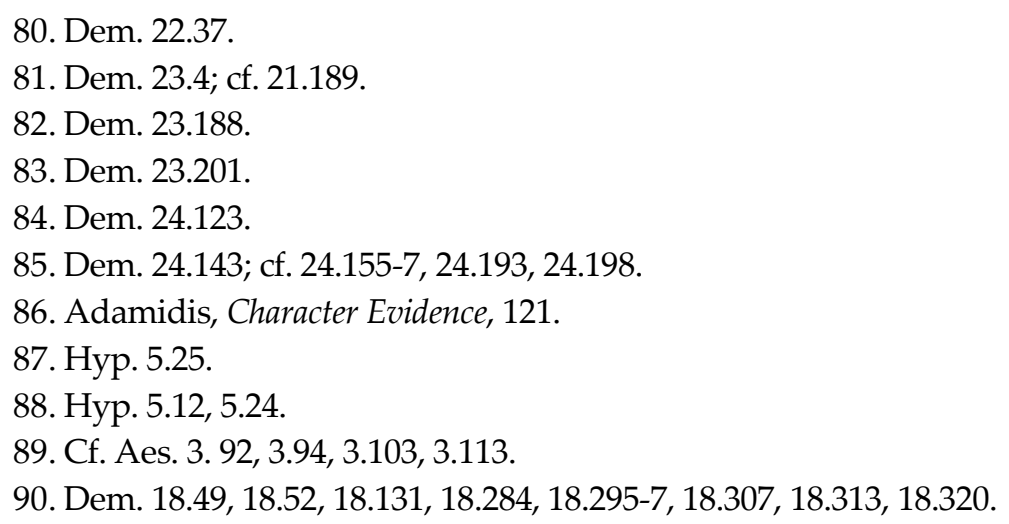


People as a group distinct from politicians and classifying the opponent as such, evidently, was an effective way to marginalize him, which was the ultimate objective.

For this to be achieved, the opponent had to be presented, using - at times aggressive rhetoric, as an ethical outsider who does not adhere to the values and norms defining the group. Arguing against Ctesiphon, Aeschines urges the Athenians to "hate people who draft illegal decrees" 91 such as his opponent. Ctesiphon (and Demosthenes) aim to "deceive the audience, harm the city, and overthrow the democratic constitution" ${ }^{\prime 2}$. When Ctesiphon calls Demosthenes as a supporting speaker, judges:

"[s]hould not listen to a sophist who thinks he will annul the laws with clever phrases, and none should count it virtuous, when Ctesiphon asks if he may call Demosthenes, to be the first to shout put: "Call him, call him"; you are calling him against yourself, against the laws, against the democratic constitution" 93

"As to his tears and his shrill voice, when he asks you: 'Where shall I find refuge, men of Athens? Shut me out of public life and there's nowhere for me to fly', you must answer him in turn: 'And the Athenian people - where are they to find refuge, Demosthenes?'"194, thus clearly separating Demosthenes from the people ${ }^{95}$. Demosthenes, in turn, claims that it is actually Aeschines who dissents from Athenian practices and should be seen as an outsider: "To be sure, it is not acceptable to try to rob someone of access to the people and the opportunity to address them and especially to do that out of spite and malice - it's not right by god, nor, Athenians, is it just or in accord with civic practice" ${ }^{\prime \prime 96}$.

Aeschines should actually be seen as the "prototype of ethical outsider of Athenian courts" 97 , namely as a sycophant ${ }^{98}$, and may he "be destroyed, first of all, by the gods but also by all these people, since you are [he is] a miserable citizen and a miserable bit-part actor" ${ }^{\prime \prime 9}$. He should be regarded as an outsider since "the valuable thing is not a politician's words or the quality of his voice, but his pursuit of the same policy as the masses and his having the same friends and

91. Aes. 3.7.

92. Aes. 3.200 .

93. Aes. 3.202.

94. Aes. 3.209.

95. Cf. Hyp. 5.12.

96. Dem. 18.13; cf. 18.34; pace Dem. 24.171.

97. Adamidis, Character Evidence, 186 with n. 109; cf. Christ, Litigious Athenian, 50ff.

98. Dem. 18.112-3; cf. 18.121-6.

99. Dem. 18.267. 
enemies as his country"100. Similarly, Hyperides attacks Philippides because he "had not laid up for yourself [himself] any good will with the people of Athens...condemned to death this ancient city...kept a close watch on the city's fortunes, to see whether an opportunity might arise to say or do anything against the people"101. Acting undemocratically, disrespecting the sovereignty of the people, "he thinks that he can give the people orders"102. The binary was present; boundaries were clearly designated and the division between the homogeneous people and the opponent-politician was highlighted.

In this division, the opponent was presented as not adhering to those venerated values that defined the identity of the interpellated group. Demosthenes's speech Against Timocrates in an action against a putatively inexpedient law is indicative: Timocrates goes against the courts, the laws, the democracy, the city, the people, and the lawgivers, namely the foundations of Athenian identity. His proposed law "robs the Courts of Justice, which are the pillars of the constitution, of their powers" 103 and has their verdicts overruled ${ }^{104}$. It invalidates "all the laws that you [People] have enacted for the restraint of evildoers"105. It is "inconsistent with all existing statutes"106, so Demosthenes is wondering "how, indeed, could any private person ill-treat the State more gravely than by subverting the laws by which the State is administered?"107 Such a person is an enemy of the people and the democracy ${ }^{108}$; he deserves to suffer any punishment as an opponent of the city ${ }^{109}$. Obviously, such a lawgiver as Timocrates, has nothing in common with wise Athenian lawgivers like Solon ${ }^{110}$ or his laws that he tries to repeal ${ }^{111}$. Throughout the speech, Timocrates is portrayed as an outsider, a person who does not respect the values, traditions, and norms of the interpellated group of the Athenian people. This rhetorical technique can be further illustrated by reference to passages placing the opponent in opposition to the ancestors ${ }^{112}$, the oaths ${ }^{113}$ and even the gods ${ }^{114}$. The objective, nonetheless,

100. Dem. 18.280 .

101. Hyp. 2.7-8.

102. Hyp. 2.10; cf. Hyp. 4.20.

103. Dem. 24.2; for a similar argument pitting the opponent against the court, see Aes. 3.53 .

104. Dem. 24.73.

105. Dem. 24.5.

106. Dem. 24.33.

107. Dem. 24.31; for a similar rhetorical technique, namely alienating the opponent from the audience by pitting him against the laws, see Aes. 3.4, 3.8, 3.16, 3.31, 3.35-7; Dem. 22.7, 22.11, 22.32, 22.45; 23.34, 23.62.

108. Dem. 24.57; cf. Dem. 22.32; 23.3, 23.98, 23.151, 23.185-8, 199; Aes. 3.8, 3.200, 3.209.

109. Dem. 24.95; cf. Hyp. 2.7-8.

110. Dem. 24.55, 24.103-6.

111. Dem. 24.142; for similar arguments pitting the opponent against the lawgivers, see Dem. 20.103, 20.158; 22.31; 23.73, 23.89; cf. Aes. 3.11.

112. Dem. 23.70. 
remains the same: excluding the opponent from the homogenous and ethically coherent People, marginalizing and alienating him in a Manichaeistic way, presenting him as a subverter of the foundations of the Athenian identity and values.

\section{Conclusions}

The rhetorical strategies of Athenian litigants shared common characteristics with modern populist discourse, whose main aim is to present a fictitious division between an artfully created pure and homogeneous People and an evil 'out-group'. References of the litigants to the dicasts as a segment of the morally pure and homogeneous Athenian demos aimed at securing their good will and establish concord. Speakers demonstrated their adherence to the traditional norms which defined Athenian identity, thus identifying themselves with the morally upright audience.

The group of dicasts was presented as an integral part of the abstract and timeless Athenian demos whose interests were endangered by the opponent. The veneration of the populace and the clear dichotomy between adherents and outsiders, achieved by artful rhetoric, paved the ground for the marginalization of the opponent who was presented as an outsider, dangerous for the values and the integrity of the group. In practical terms, aggressive and anti-pluralist rhetoric aimed at the incitement of thorubos, which impeded the opponent from stating his case. This Manichaeistic approach of Athenian litigants, similar to the rhetorical strategies employed in modern populism, can certainly enlighten students of modern political, especially populist, discourse.

\section{Bibliography}

Abts, Koen and Rummens, Stefan. "Populism versus Democracy." Political Studies 55, no. 2 (2007): 405-424.

Adamidis, Vasileios. Character Evidence in the Courts of Classical Athens: Rhetoric, Relevance and the Rule of Law. London and New York: Routledge, 2017.

Adamidis, Vasileios. "The Relevance of Liturgies in the Courts of Classical Athens." Athens Journal of History 3, no. 2 (2017): 85-96.

Adamidis, Vasileios. "Solon the Lawgiver: Inequality of Resources and Equality before the Law," in the Role of law, human rights and social justice, justice systems, commerce, and law curriculum: selected issues, edited by David A. Frenkel (Athens: ATINER, 2017): 121-138.

113. Dem. 20.167; Aes. 3.208.

114. Aes. 3.130; Dem. 18.267. 
Adamidis, Vasileios. "Manifestations of populism in late 5th century Athens." In New studies in law and history, edited by David. A. Frenkel and Norbert Varga, 11-28. Athens: Athens Institute for Education and Research, 2019.

Barr, Robert, R., "Populists, Outsiders and Anti-Establishment Politics." Party Politics 15, no. 1 (2009): 29-48.

Bers, Victor. "Dikastic Thorubos." History of Political Thought 6, no. 1/2 (Summer 1985): 1-15.

Blanshard, A.J.L. 2004. "What Counts as the demos? Some Notes on the Relationship between the Jury and "The People" in Classical Athens." Phoenix 58: 28-48.

Cairns, Douglas L. Aidōs: the psychology and ethics of honor and shame in ancient Greek literature. Oxford: Clarendon, 1993.

Canovan, Margaret. "Taking Politics to the People: Populism as the Ideology of Democracy." in Democracies and the Populist Challenge, edited by Yves Mény and Yves Surel, 25-44. New York: Palgrave, 2002.

Cartledge, Paul. Democracy: A Life. Oxford: Oxford University Press, 2016.

Christ, Matthew R. The Litigious Athenian. Baltimore: Johns Hopkins University Press, 1998.

Connor, W.R. The New Politicians of Fifth-Century Athens. Princeton, N.J.: Princeton University Press, 1971.

De La Torre, Carlos. Populist Seduction in Latin America. Ohio: Ohio University Press, 2010.

De La Torre, Carlos and Mazzoleni, Oscar. "Do We Need a Minimum Definition of Populism? An Appraisal of Mudde's Conceptualization," Populism 2, no. 1 (2020): 79-95.

Fortenbaugh, William. "Aristotle on Persuasion through Character." Rhetorica, 10:3 (1992): 207-44.

Gagarin, Michael. "Storytelling about the Lawgiver in the Athenian Orators." CEA (2020): 33-44.

Gallie, W.B. "Essentially Contested Concepts." Proceedings of the Aristotelian Society 56, no. 1 (1956): 167-98.

Hansen, Mogens H. "The Athenian 'Politicians'," 403-322 B.C.' Greek, Roman and Byzantine Studies 24 (1983): 33-55.

Harris, Edward M. "Law and Oratory." In Persuasion: Greek Rhetoric in Action, edited by Ian Worthington, 130-50. London: Routledge, 1994.

Harris, Edward M. "Solon and the Spirit of the Law in Archaic Athens." In Democracy and the Rule of Law in Classical Athens: Essays on Law, Society, and Politics, edited by Edward M. Harris, 3-28. New York: Cambridge University Press, 2006.

Harris, Edward M. "The Rule of Law in Athenian democracy. Reflections on the judicial oath," Dike 8 (2008): 157-81.

Harris, Edward M. The Rule of Law in Action in Democratic Athens. New York: Oxford University Press, 2013. 
Hawkins, Kirk A. "Is Chavez Populist? Measuring Populist Discourse in Comparative Perspective." Comparative Political Studies 42, no. 8 (2009): 10401067.

Huhn, Wilson. The Five Types of Legal Argument. (Durham, NC: Carolina Academic Press, 2014).

Johnstone, Stephen. Disputes and Democracy: The Consequences of Litigation in Ancient Athens. Austin: University of Texas Press, 1999.

Kazin, Michael. The Populist Persuasion. Ithaca, NY: Cornell University Press, 1995.

Laclau, Ernesto. The Populist Reason. London: Verso, 2005.

Maltagliati, Giulia. "Persuasion through proximity (and distance) in the Attic orators' Historical Examples." Greek, Roman, and Byzantine Studies 60, No. 1 (2020): 68-97.

McGlew, James F. "Speak on my Behalf": Persuasion and Purification in Aristophanes' Wasps." Arethusa 37 (2004): 11-36.

Moffitt, Benjamin. The Global Rise of Populism: Performance, Political Style and Representation. Stanford, California: Stanford University Press: 2016.

Mudde, Cas. "The Populist Zeitgeist." Government and Opposition 39, no. 4 (2004): 541-63.

Mudde, Cas. "Populism: An Ideational Approach." In The Oxford Handbook of Populism edited by C. Rovira Kaltwasser, P. Taggart, P. Ochoa Espejo, P. Ostiguy, 27-47. Oxford: Oxford University Press.

Mudde, Cas and Rovira Kaltwasser, Cristobal. "Populism and (Liberal) Democracy: A Framework for Analysis." In Populism in Europe and the Americas: Threat or Corrective for Democracy?, edited by Mudde, Cas and Rovira Kaltwasser, Cristobal, 1-26. Cambridge: Cambridge University Press, 2012.

Mudde, Cas and Rovira Kaltwasser, Cristobal. Populism. A Very Short Introduction. Oxford: Oxford University Press 2017.

Mudde, Cas and Rovira Kaltwasser, Cristobal. "Studying Populism in Comparative Perspective: Reflections on the Contemporary and Future Research Agenda." Comparative Political Studies 51, no. 13 (2018): 1667-93.

Müller, Jan-Werner. What Is Populism? Philadelphia: University of Pennsylvania Press, 2016.

Ober, Josiah. The Athenian Revolution: Essays on Ancient Greek Democracy and Political Theory. Princeton: Princeton University Press, 1996.

Ostwald, Martin. From Popular Sovereignty to the Sovereignty of the Law: Law, Society, and Politics in Fifth-Century Athens. (Berkeley, Los Angeles, London: University of California Press, 1986).

Reisigl, Martin. "Analyzing Political Rhetoric." In Qualitative Discourse Analysis in the Social Sciences, edited by Ruth Wodak and Michał Krzyżanowski, 96-120. New York: Palgrave Macmillan, 2008.

Rhodes, Peter J. A Commentary on the Aristotelian Athenaion Politeia. Oxford: Clarendon Press, 1981. 
Stanley, Ben. "The Thin Ideology of Populism." Journal of Political Ideologies 13, no. 1 (2008): 95-110.

Stavrakakis, Yiannis and Katsambekis, Georgios. "Left-wing populism in the European periphery: the case of SYRIZA." Journal of Political Ideologies 19, no. 2 (2014): 119-142.

Szegedy-Maszak, A. “Legends of the Greek Lawgivers.” GRBS 19 (1978): 199-209.

Taggart, Paul "Populism and 'Unpolitics'," in Populism and the Crisis of Democracy, Vol. 1: Concepts and Theory, edited by G. Fitzi, J. Mackert, and B.S. Turner, (London: Routledge, 2018): 79-87.

Weyland, Kurt. "Clarifying a Contested Concept: Populism in the Study of Latin American Politics." Comparative Politics 34, no. 1 (2001): 1-22, 14.

Worthington, Ian, ed. Persuasion: Greek Rhetoric in Action. London: Routledge, 1994. 